\title{
EFFECT OF HULLING MACHINES ON HULLING CHARACTERISTICS AND QUALITY OF RICE GRAINS
}

\author{
Mohamed E. Yehia* and A. R. Katab*
}

\begin{abstract}
During milling process, the convention to husk paddy rice is pass it between two rubber rollers that are rotating with a surface speed different. The resulting normal pressure and shear stress causes the husk to be peeled away from kernel. This operation is one of the most important stages, which effectively determines the quantitative and qualitative losses of rice. The main aim of this research was to evaluate the hulling characteristics of different rubber roll type huskers (adjust the clearance one manually and the other by pressing the air) using paddy rice variety Giza 179 as a short grain was studied based on some technical indicators. Two types of machines (THU-35A and HR-10 MPc) were used. The results showed that the operational parameters for Optimum operational efficiency are: $0.9 \mathrm{~mm}$ clearance and 1.4 Speed ratio, the husker machine model (SATAKE THU-35A). For the husker machine model (SATAKE HR-10 MPc) at constant speed ratio of 1.25, the optimum operational efficiency are: $3.3 \mathrm{Kg} / \mathrm{cm}^{2}$ pneumatic pressure and $90 \mathrm{Kg} / \mathrm{min}$. feeding rate for the Husker machine (HR-10 MPc) at constant speed ratio of 1.25. To describe the effect the efficiency of paddy hulling, the percentage of broken grain and the power consumption's of husker machines as a function of paddy feeding rate, rubber roll clearance and speed ratio a computer programmer for regression analysis were used.
\end{abstract}

\section{INTRODUCTION}

ice is one of the most important cereals and the staple food of
two-thirds the world's population as the primary dietary source
of carbohydrate and energy (Zhout \& Mazad. 2002, Hu et al., 2004 and Denardin et al., 2007). As a global food, it has a large influence on human nutrition and food security all over the world.

*Res, Rice Technology Training Center, Field Crops Research Institute, A.R.C., Alexandria, Egypt. 
After wheat, rice is the second major food source in Egypt, Because of population increases, limited cultivated land and limits in water resources it is very important to decrease rice losses.

One of the major problems of rice milling industry is breakage of grains during the process of milling. The type of rice mill and the method of operation affect the recovery and quality of milled rice significantly. Milling loss has been estimated to range from 2 to $10 \%$ (DE-Padua, D.B., 1976).This loss represents a serious reduction of this main staple food. Milling industry in Egypt uses both machines of different types and designs. Hence the operational characteristics of such machines most be well established and understood for minimizing milling losses.

Milling is the final step in rice post-harvest processing, which includes pre-cleaning, husking, whitening and grading in the rice milling process (Ohtsubo et al., 2005).

Some of quality losses occur during paddy hulling in the milling operation because it is a mechanical operation which causes stresses in the rice kernel. Rice breakage at this stage is one of the main economic losses to the Producers.

Soliman N. S. 1987 said that the compressive load resistance of rice grain is based on its characteristic of yield strength of which can be expressed as relationships of the shear strength as well as lowering the broken rice during the rice mill processes, the machines are adjusted according to the experience of the operator.

The broken grain size which is less than a quarter of the length is due to several factors, grouped these factors under two broad categories namely: (a) factors associated $b$ with rice and (b) factors associated with machine. Factors associated with paddy include; (I) varietal characteristics, (2) production factors, and (3) post production Operations prior to milling, the miller may have no control of these factors. Factors associated with the machine can be more or less controlled and include machine type, machine adjustments systems and their operation (Harry T.L., 1982, Chaitep et al., 2008 and Al Sharifi, 2010).

According to Firouzi et al., 2010 and Williams et al., 2002 rubber roll husker is a common type used for paddy husking in many rice growing countries. In principle, the rubber roll husker consists of two rubber 
rollers, one has a fixed position; the other is adjustable to obtain the desired clearance between the two rollers. The rollers are driven mechanically and rotate in opposite directions, the adjustable roller normally running about 30 percent slower than the fixed one to create shearing effect Both rollers have the same diameter.

Shitanda et al. (2001) studied the Performance of experimental impeller and rubber roller huskers using three different varieties of paddy. Results of their study showed that rubber roll husker had high husking energy efficiency compared to the impeller husker.

Correa et al. (2007) considered engineering properties of rough rice, brown and milled rice to determine the influence of the rice processing operations on physical and mechanical properties of different rice varieties.

Razavi and Farahmandfar (2008), evaluated the effect of husking and milling on the physical properties of rice grains, they reported that the physical characteristics of rice significantly affected by milling process.

Another experiment was conducted by Omar and Yamashita (1987) on laboratory rubber roller and impeller paddy husker. Results showed that the clearance ratio of 0.5 resulted in husking ratio higher than $80 \%$ and lower broken rice ratio than the other levels.

Payman et al. (2006) determined the most suitable spacing between rubber rolls for increasing husking percentage and reducing rice breakage in the test huller.

A report by Garibaldi, F. (1988) indicated that modern mills using rubberroll huskers gave an average overall increase in total rice recovery of 2.5 $\%$ over a disk-husker type rice mill and $6.6 \%$ over the Engelberg husker machine.

In Egypt, three types of the rubber roll huskers are now being used a great deal in the milling industry. One type has two rolls that rotate in opposite directions at the same angular speed but their diameters are different. The other type has two rolls of the same diameter but they rotate at different angular speeds. The clearances between rolls in these two types are adjusted manually by a hand wheel. A third and more modern type differs from the two other types. Pneumatic pressure control by which the clearance is automatically adjusted according to the feed rate. There are 
no performance curves available which describe the characteristics of each husking machine for the paddy rice grown in Egypt.

For that the objective of this study is to test the effect of some operational parameters of these husking machines. This will enable us to establish some machine performance relations with which Optimum Operation can be obtained.

\section{MATERIALS AND METHODS}

Certified seeds Short grain rice variety of Giza 179 cultivar were provided by from the experimental farm of Rice Research Training Center (RRTC) at Sakha, Kafr-Elsheikh governorate, during 2016 rice growing season. This study was carried out and tested at the rice mill and laboratories of Rice Technology Training Center (RTTC) Alexandria Egypt. This cultivar however has a defect in its milling characters. The broken percentage reaches more than $25 \%$ which reduces commercial value. The paddy at $14.1 \%$ moisture content (w.b.) was cleaned by a seed blower and a thickness grader model TWS for grading grains according to their thickness, the hexagonal screen is supplied with mesh of $1.6 \mathrm{~mm}$ as a standard, Input capacity $600 \mathrm{~g} / \mathrm{one}$ time and stored at room temperature in a plastic container until tested. The moisture content was determined by the oven method $\left(130^{\circ} \mathrm{C}\right.$ for $18 \mathrm{hr}$.) model TS-400. The particle length; width and thickness were measured with a plate form type dial micrometer model MK-200, measuring rang 0:20mm.

In this experiment, the effect of two different types of rubber roll huskers (adjust the clearance one manually and the other by pressing the air); Satake model (HR $10 \mathrm{MP}_{\mathrm{C}}$ ) and Satake model (THU-35 A) were tested in this study. In the two machines the feeding rate is controlled by a feeding roll both rolls revolve in opposite directions at different speeds. The clearance between the two surfaces must be smaller than the mean thickness of the rice kernel. The hulls covering the kernel are first compressed. The part of the hull which hits against the roll with the higher peripheral speed is subjected also to shearing forces. Hulling is achieved by the action of these two forces.

Paddy Husker model (SATAKE HR-10 $\mathrm{HP}_{\mathrm{C}}$ ) has two horizontal tangential rubber rolls, $254 \mathrm{~mm}$ diameter each; revolving in opposite direction at different speeds 800 r.p.m. and 1000 r.p.m. (speed ratio is 
1.25). The pressure on the paddy between the rolls can be regulated by a pneumatic valve. The machine is driven by a 5.5 kilowatt motor.

Paddy Husker model (SATAKE THU-35 A) has two tangential rubber rolls, size of rubber roll width $35 \mathrm{x}$ Dia. $100 \mathrm{~mm}$ diameter each revolving in opposite direction and at different speeds. The lower speed is fixed at 800r.p.m. and the higher speed can be adjusted to $1000,1200,1400$ or 1600 r.p.m. The clearance between the rolls was adjusted to the desired clearance. The machine is driven by a 400.0 watt motor, single phase, and capacity on paddy $50 \mathrm{~kg} / \mathrm{hr}$.

The experiments were divided into two groups. The first groups were carried out using Paddy Husker model (STAKE THU-35 A). A total number of 90 experiments were conducted at one level of feeding rate, Q $(30 \mathrm{Kg} / \mathrm{hr}$ ), three levels of speed ratio, $\mathrm{K}(1.25,1.5$ and 1.75) and six levels of clearance, $\delta(0.5,0.75,1.0,1.25,1.5$ and $1.75 \mathrm{~mm})$. Each treatment was run in three replicates and the sample size was 200 gram.

The second group was carried out using Paddy Husker model (STAKE HR-10 $\left.\mathrm{MP}_{\mathrm{c}}\right)$ at a constant speed ratio $(\mathrm{K}=1.25)$. A total number of 120 experiments were conducted at six levels of pneumatic pressure $(1.5 ; 2.0$; $2.5,3.0,3.5$ and $\left.4.0 \mathrm{Kg} / \mathrm{cm}^{2}\right)$, and four levels of feeding rate $(15,30,45$ and $60 \mathrm{Kg} / \mathrm{min}$.). The duration of each experiment was five minute. Each treatment was run in five replicates selected randomly. Prior to running any experiment, all hulled, immature and broken grain was removed from the sample.

The machine performance was measured by the following:

1) Hulling efficiency (HE), defined as,

Where;

$$
\mathrm{HE}=\frac{W_{e}}{W s} \times 100
$$

$W_{e}=$ weight of hulling grain, gr.

$W_{s}=$ weight of paddy hulling sample, gr.

2) Broken of percentage (BR), defined as;

$$
\mathrm{BR}=\frac{W_{b}}{W s} \times 100
$$

Where; $W_{b}=$ weight of broken rice grain, gr.

3) Overall hulling coefficient (OHC), defined as,

$$
\mathrm{OHC}=W_{e} / W_{s} \times\left(1-\frac{W b}{W e}\right)
$$


4) The feeding rate ratio (FR) is defined as the ratio of the actual feeding rate $(\mathrm{Q})$ to the maximum feeding rate $\left(\mathrm{Q}_{\max }\right)$ at the specified roll speeds (given by the manufacturer).

5) The power ratio (Pr) is defined as the ratio of the actual power consumption to the maximum power consumption at the specified roll speeds.

The electric energy consumption for each test was measured in kilowatt/hr using a sensitive kilowatt/hr. meter. The author introduces here an operational efficiency (OE) as a general measure for the technological performance and mechanical performance of the husker. The Operational efficiency is defined as:

$$
\mathrm{OE}=\mathrm{OHC} \times \frac{f_{r}}{P r} \times 100
$$

\section{RESULTS AND DISCUSSION}

\section{Physical properties}

Some physical properties of rice variety Giza 179, the three principal dimensions length, width and thickness of rough rice were measured for 100 kernels. Average values were obtained as $7.83 \mathrm{~mm} ; 3.28 \mathrm{~mm}$ and 2.16 $\mathrm{mm}$ respectively. The average weight of 1000 kernels $(\mathrm{M})$ was 24.04 gram, and the average moisture content of rough rice was $14.0 \pm 0.2 \%$ (w.b.).

\section{A. Paddy Husker model (SATAKE THU-35 A):}

The data showed that the paddy hulling efficiency, grain broken percentage and power consumption were the highest at the smallest clearance in the range. The results showed that there was a significant effect of each factor; however, the roll clearance has the highest significance of all. The effect of the speed ratio was strong at low levels of roll clearance but had very little effect on grain broken percentage at high levels of clearance.

The effect of roll clearance levels and different speed ratio on paddy hulling efficiency, grain broken percentage, and power consumption are shown graphically in Figures (1,2 and 3) significant differences of paddy hulling efficiency, grain broken percentage, and power consumption were found. 


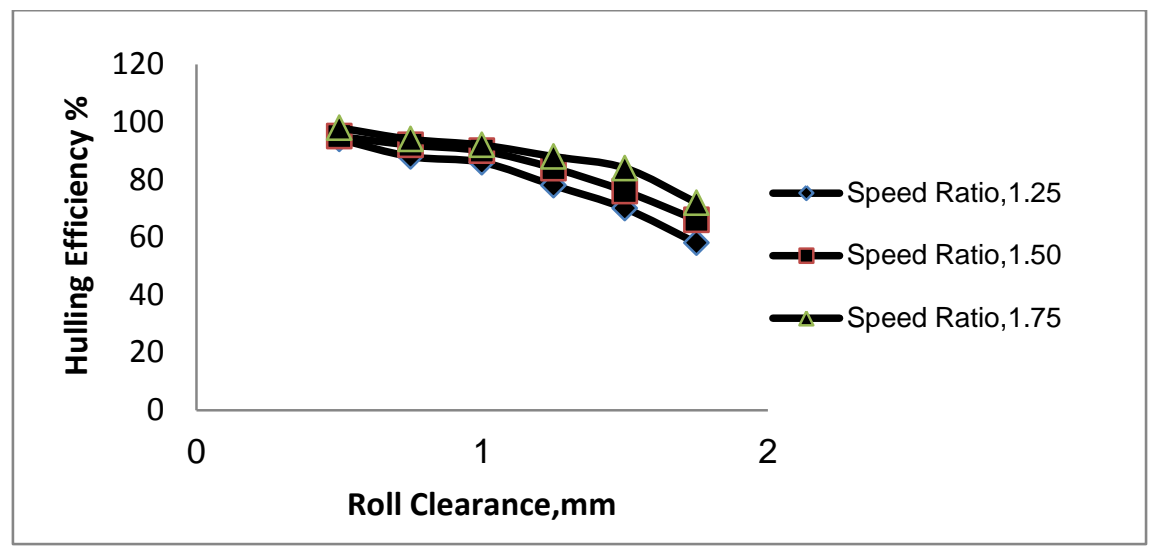

Fig. (1a): Effect of roll clearance and speed ratio on hulling efficiency at constant feeding rate $30 \mathrm{Kg} / \mathrm{hr}$, for the paddy husker model (THU- 35A)

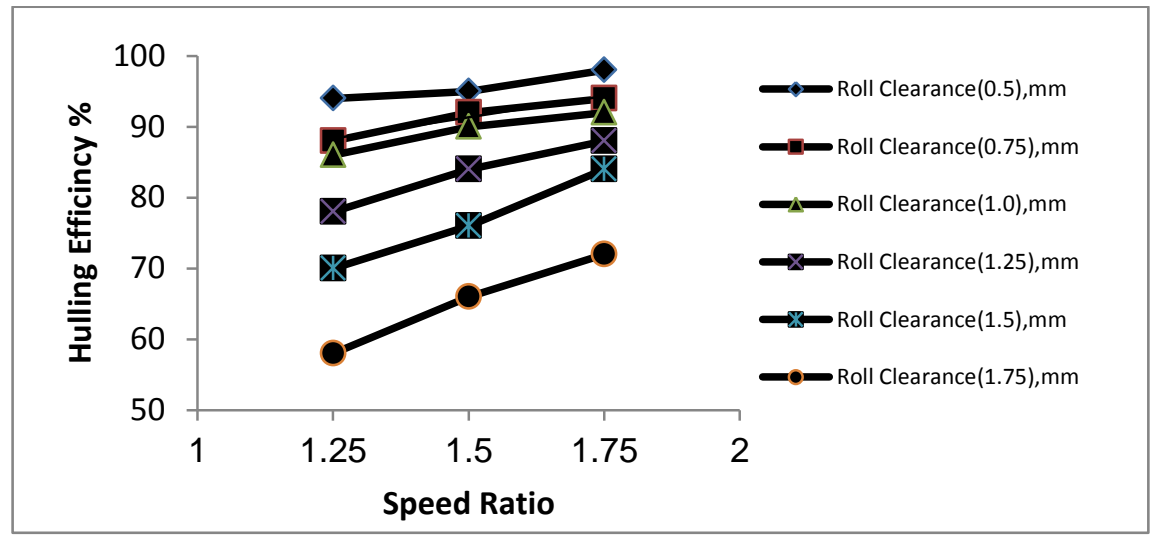

Fig. (1b): Effect of speed ratio and roll clearance on hulling efficiency at constant feeding rate $30 \mathrm{Kg} / \mathrm{hr}$, for the paddy husker model (THU- 35A)

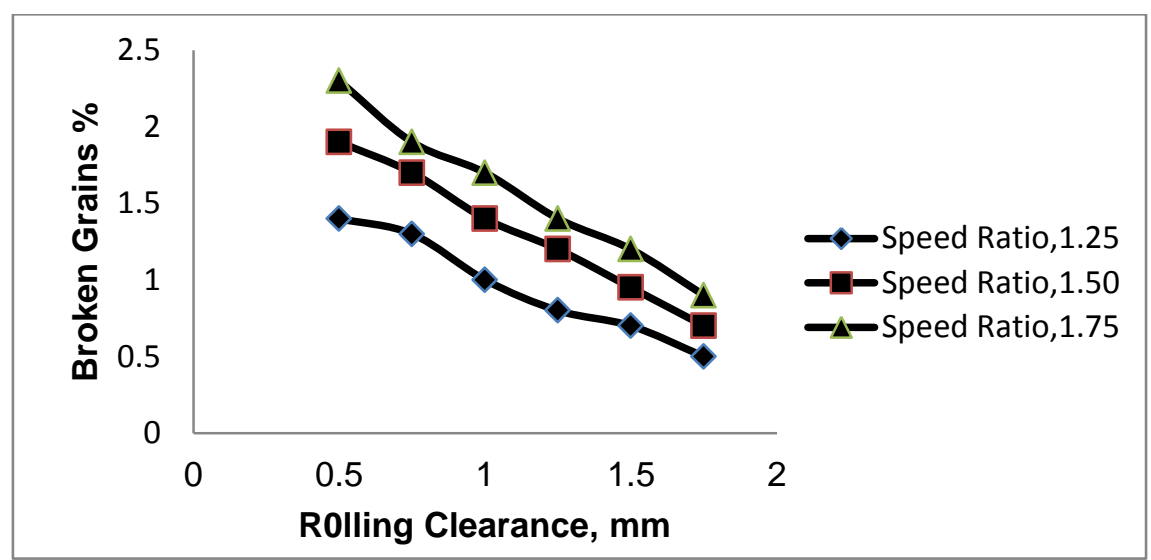

Fig. (2a): Effect of roll clearance and speed ratio on broken percentage at constant feeding rate $30 \mathrm{Kg} / \mathrm{hr}$, for the paddy husker model (THU- 35A) 


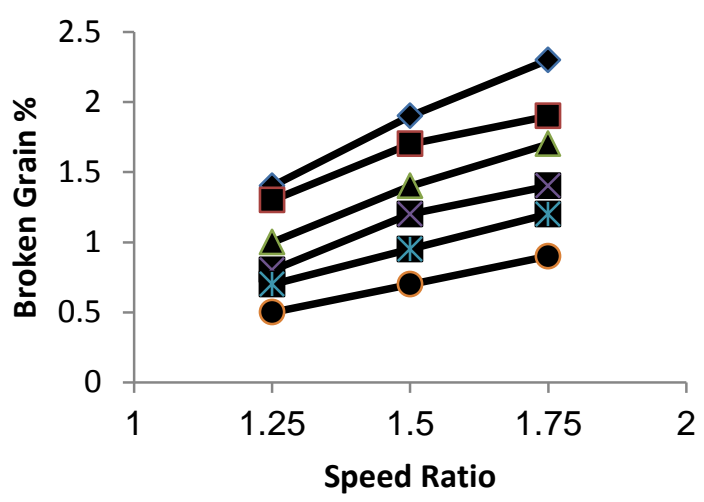

$\longrightarrow$ Roll Clearance(0.5),mm -Roll Clearance(0.75),mm

- Roll Clearance(1.0),mm

$\longrightarrow$ Roll Clearance(1.25),mm

$-\mathbb{E}$ Roll Clearance(1.5), mm

- Roll Clearance(1.75),mm

Fig. (2b): Effect of speed ratio and roll clearance on broken percentage at constant feeding rate $30 \mathrm{Kg} / \mathrm{hr}$, for the paddy husker model (THU- 35A)

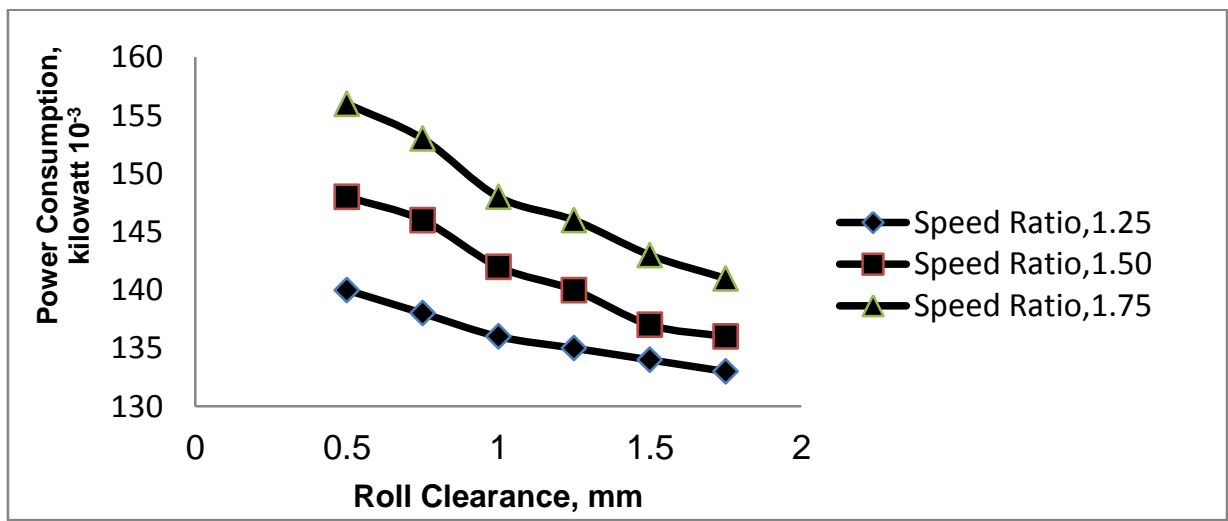

Fig. (3a): Effect of roll clearance and speed ratio on power consumption at constant feeding rate $30 \mathrm{Kg} / \mathrm{hr}$, for the paddy husker model (THU- 35A)

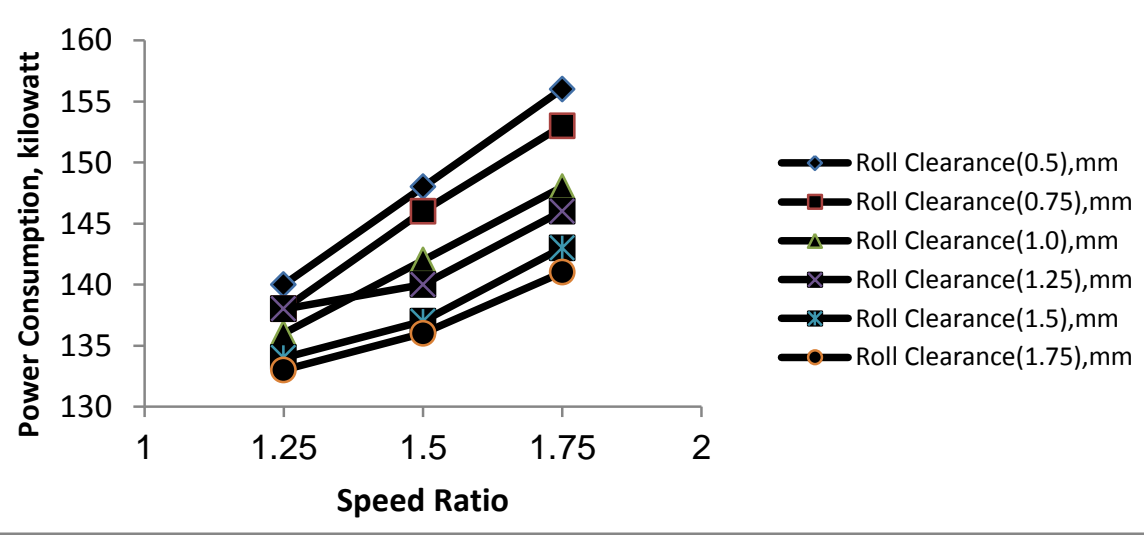

Fig. (3b): Effect of speed ratio and roll clearance on power consumption at constant feeding rate $30 \mathrm{Kg} / \mathrm{hr}$, for the paddy husker model (THU- 35A) 
Multiple regression analysis was used to develop mathematical forms to describe the paddy hulling efficiency at different speed ratio in equations (1, 2 and 3) with the high values of $R^{2}$,

At (SR, 1.25)

$\mathrm{HE}, \%=15.42(\mathrm{RC}, \mathrm{mm})^{2}+7.057(\mathrm{RC}, \mathrm{mm})+93.4$

$\mathrm{R}^{2}=0.992$

At (SR, 1.50)

$\mathrm{HE}, \%=16.85(\mathrm{RC}, \mathrm{mm})^{2}+15.18(\mathrm{RC}, \mathrm{mm})+91.15$

$\mathrm{R}^{2}=0.997$

At (SR, 1.75)

$\mathrm{HE}, \%=13.71(\mathrm{RC}, \mathrm{mm})^{2}+12.11(\mathrm{RC}, \mathrm{mm})+94.22$

$\mathrm{R}^{2}=0.997$

Also describe the grain broken percentage (BG, \%) in equations (4, 5 and 6) with $R^{2}=(0.981,0.998$ and 0.99) respectively,

At (SR, 1.25)

$\mathrm{BG}, \%=-0.742(\mathrm{RC}, \mathrm{mm})+1.785$

$\mathrm{R}^{2}=0.981$

At (SR, 1.50)

$\mathrm{BG}, \%=-0.965(\mathrm{RC}, \mathrm{mm})+2.394$

$\mathrm{R}^{2}=0.998$

At (SR, 1.75)

$\mathrm{BG}, \%=-1.074(\mathrm{RC}, \mathrm{mm})+2.775$

$\mathrm{R}^{2}=0.991$

Equations (7, 8 and 9) were describe the power consumption (PC, Watt) with $\mathrm{R}^{2}=(0.970,0.99$ and 0.983$)$ respectively as functions of roll clearance $(\mathrm{mm})$ and speed ratio $(\mathrm{K})$ at consent.

The following linear equations were obtained:

At (SR, 1.25)

$\mathrm{PC}, \mathrm{Watt}=142.2 \mathrm{e}-0.04(\mathrm{RC}, \mathrm{mm})$

$\mathrm{R}^{2}=0.970$ 
At (SR, 1.50)

$\mathrm{PC}, \mathrm{Watt}=153.3 \mathrm{e}-0.07(\mathrm{RC}, \mathrm{mm})$

$\mathrm{R}^{2}=0.9$

At (SR, 1.75)

$\mathrm{PC}, \mathrm{Watt}=162.1 \mathrm{e}-0.08(\mathrm{RC}, \mathrm{mm})$

$\mathrm{R}^{2}=0.983$

\section{Paddy Husker model (SATAKE HR 10 MP ${ }_{\mathrm{C}}$ ):}

The effect of pneumatic pressure $\left(\mathrm{P}, \mathrm{Kg} / \mathrm{cm}^{2}\right)$ and feeding rate $(\mathrm{Q}$, $\mathrm{Kg} / \mathrm{min}$ ) on hulling percentage, broken percentage and power consumption (P.C., watt) are shown graphically in Figures (4,5 and 6). The rubber roll husker machine indicated that the broken percentage and power consumption are very similar and increase-as pneumatic pressure and feeding rate increase, while the hulling efficiency increases as pneumatic pressure increases and decreases as the feeding rate increases. In this experimental work it is desired to investigate how the changes in pneumatic pressure and feeding rate affect the broken percentage, hulling efficiency and power consumption.

A computer programmer for multiple regression analysis was used to develop mathematical forms to describe the hulling efficiency, the broken grains percentage and the power consumption as functions of the pneumatic pressure and the feeding rate.

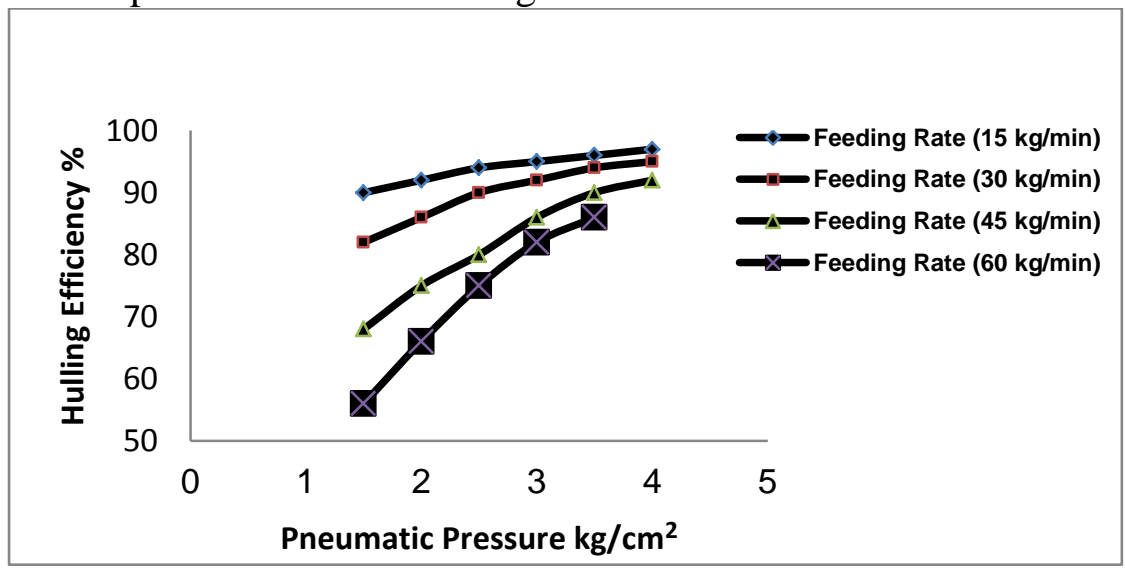

Fig. (4): Effect of pneumatic pressure and feeding rate on hulling percentage, for husker model (HR-10MPc) 


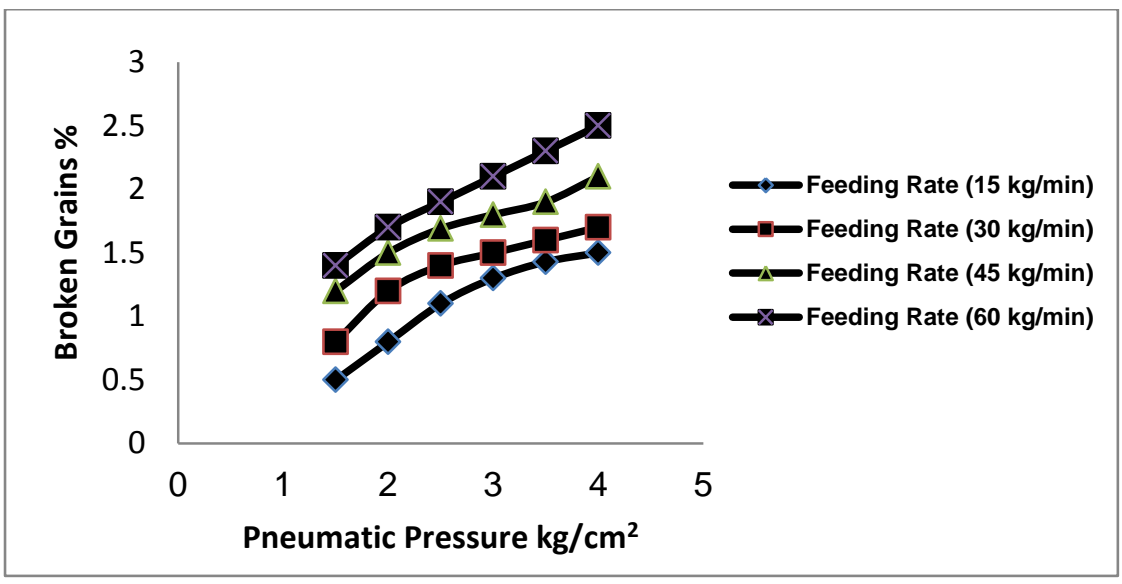

Fig. (5): Effect of pneumatic pressure and feeding rate on broken percentage, for husker model (HR-10MPc)

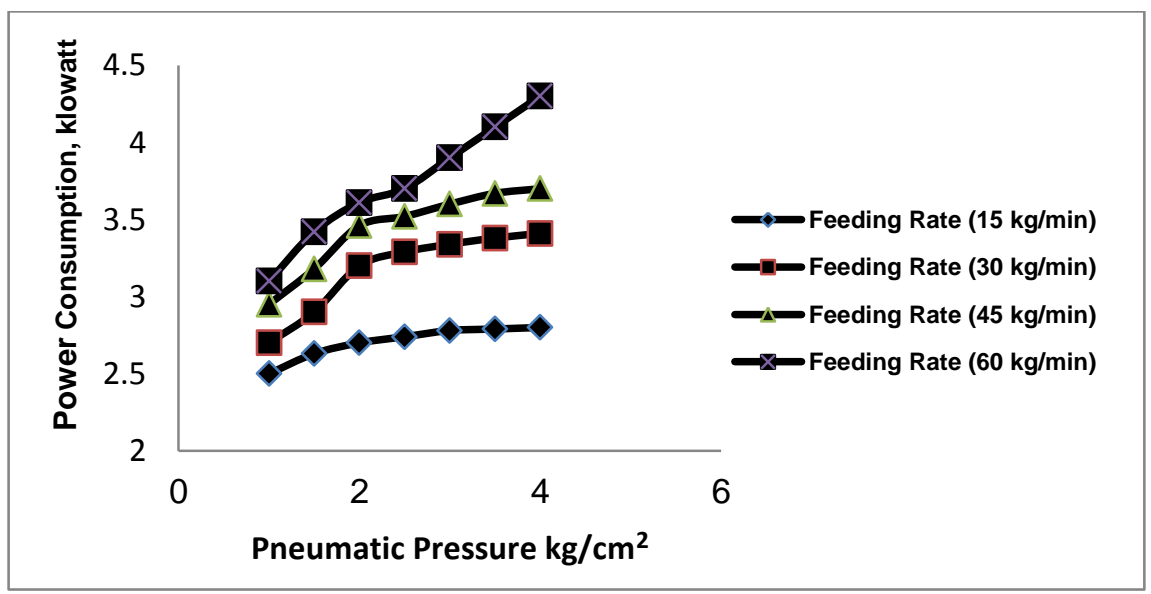

Fig. (6): Effect of pneumatic pressure and feeding rate on power consumption, for husker model (HR-10MPc)

Equations (10,11,12 and 13) of paddy hulling efficiency at different feeding rate were obtained as following.

At $(\mathrm{FR}, 15 \mathrm{~kg} / \mathrm{min})$

$\mathrm{HE}, \%=7.125 \ln \left(\mathrm{PP}, \mathrm{kg} / \mathrm{cm}^{2}\right)+87.16$

$\mathrm{R}^{2}=0.989$

At (FR, $30 \mathrm{~kg} / \mathrm{min})$

$\mathrm{HE}, \%=13.61 \ln \left(\mathrm{PP}, \mathrm{kg} / \mathrm{cm}^{2}\right)+76.78$

$\mathrm{R}^{2}=0.990$ 
At (FR, $45 \mathrm{~kg} / \mathrm{min})$

$\mathrm{HE}, \%=25.29 \ln \left(\mathrm{PP}, \mathrm{kg} / \mathrm{cm}^{2}\right)+57.58$

$\mathrm{R}^{2}=0.995$

At (FR, $60 \mathrm{~kg} / \mathrm{min})$

$\mathrm{HE}, \%=36.30 \ln \left(\mathrm{PP}, \mathrm{kg} / \mathrm{cm}^{2}\right)+41.29$

$\mathrm{R}^{2}=0.997$

Equations (14,15,16 and 17) of paddy broken grains percentage at different feeding rate were obtained as following.

At (FR, $15 \mathrm{~kg} / \mathrm{min})$

$\mathrm{BG}, \%=1.0601 \ln \left(\mathrm{PP}, \mathrm{kg} / \mathrm{cm}^{2}\right)+0.088$

$\mathrm{R}^{2}=0.989$

At $(\mathrm{FR}, 30 \mathrm{~kg} / \mathrm{min})$

$\mathrm{BG}, \%=0.878 \ln \left(\mathrm{PP}, \mathrm{kg} / \mathrm{cm}^{2}\right)+0.524$

$\mathrm{R}^{2}=0.965$

At (FR, $45 \mathrm{~kg} / \mathrm{min})$

$\mathrm{BG}, \%=0.8601 \ln \left(\mathrm{PP}, \mathrm{kg} / \mathrm{cm}^{2}\right)+0.878$

$\mathrm{R}^{2}=0.987$

At (FR, $60 \mathrm{~kg} / \mathrm{min})$

$\mathrm{BG}, \%=1.0961 \ln \left(\mathrm{PP}, \mathrm{kg} / \mathrm{cm}^{2}\right)+0.931$

$\mathrm{R}^{2}=0.993$

Equations $(18,19,20$ and 21$)$ of power consumption at different feeding rate were obtained as following.

At (FR, $15 \mathrm{~kg} / \mathrm{min})$

$\mathrm{PC}, \mathrm{Watt}=0.216 \ln \left(\mathrm{PP}, \mathrm{kg} / \mathrm{cm}^{2}\right)+2.528$

$\mathrm{R}^{2}=0.961$

At (FR, $30 \mathrm{~kg} / \mathrm{min})$

$\mathrm{PC}, \mathrm{Watt}=0.535 \ln \left(\mathrm{PP}, \mathrm{kg} / \mathrm{cm}^{2}\right)+2.734$

$\mathrm{R}^{2}=0.949$

At (FR, $45 \mathrm{~kg} / \mathrm{min})$

$\mathrm{PC}, \mathrm{Watt}=0.553 \ln \left(\mathrm{PP}, \mathrm{kg} / \mathrm{cm}^{2}\right)+2.984$ 


$$
\mathrm{R}^{2}=0.969
$$

At (FR, $60 \mathrm{~kg} / \mathrm{min})$

$\mathrm{PC}, \mathrm{Watt}=0.816 \ln \left(\mathrm{PP}, \mathrm{kg} / \mathrm{cm}^{2}\right)+3.062$

$\mathrm{R}^{2}=0.970$

\section{CONCLUSIONS}

The following conclusions from the results of this study hulling efficiency, broken percentage and power consumption for a husker machine are affected significantly by roll clearance, feeding rate and speed ratio adjustments. Proper selection of clearance adjustments, Speed ratio and feeding rate plays a major role in the effectiveness of the hulling process as it improves the hulling efficiency. The optimum operational conditions of the paddy husker model (THU-35 A) can be obtained by adjusting the machine to $0.9 \mathrm{~mm}$ clearance, and 1.4 Speed ratio, while the optimum operational conditions of paddy husker model (HR-10 MPc) can be obtained by adjusting the machine to $3.3 \mathrm{Kg} / \mathrm{cm}^{2}$ pneumatic pressure and $90 \mathrm{Kg} / \mathrm{min}$. feeding rate at constant Speed ratio 1.25. Some physical properties of rice are necessary for drying, Storage, storage equipment, equipment processing and handling, transport and processing design, especially peeling process to reduce the loss, adjust machines which give them productivity of whole grains and higher quality.

\section{REFERENCES}

Al Sharifi, S. K. A. 2010. Effect of different husking and whitening machines to rice kernel varieties Abasiya and Mushkhab 1 for both seasons 2006, 2007. Euphrates Journal of Agriculture Science, 2(3):11-35.

Chaitep, S., R. Chaiy, and W. Pipatpong. 2008. Compressive load resistance characteristics of rice grain. American Journal of Agricultural and Biological, 3(1):325-329.

Correa, PC, Schwanz da Silva F, Jaren C, Afonso Junior PC, Arana I, 2007. Physical and mechanical properties in rice processing. J F Eng 79(1): 137-142. 
Denardin, C.C., M. Walter, L. P. Silva, G. D. Souto and C. A. Fagundes, 2007. Effect of amylose content of rice varieties on glycemic metabolism responses in rats on glycemic metabolism and biological responses in rats. Food Chemistry, vol. 105, pp. 14741479 .

DE-PADUA, D. B. Rice Post-Production Handling and Processing, 1976. Its significance to Agricultural Development. Paper Presented at the International Workshop on accelerating Agricultural Development. SEARCA. Los Banos, Laguna, Philippines, April 26-30.

Firouzi, s., M. Alizadeh, and S. Minaei, 2010. Effect of Rollers Differential Speed and Paddy Moisture Content on Performance of Rubber Roll Husker. International Journal of Natural and Engineering Sciences 4 (3): 37-42.

Gariboldi, F., 1988. Rice Milling equipment Operation and maintenance. Rome: food and Agricultural (FAO) of the United Nations.

HARY, TH. L. VAN RUITEN, 1982. The post-harvest processing of paddy in the humid tropics as related to milling recoveries. Documentation of the GASGA-Seminar "Paddy deterioration in the Humid Tropics" Baguio, Philippines, Eschborn, Page 163-176.

Hu, H., H. Zhao, Z. Duan, Z. Linlin and D. Wu. 2004. Starch digestibility and the estimated glycemic score of different types of rice differing in amylose contents. Journal of Cereal Science, vol. 40, pp. 231237.

Ohtsubo, K., K. Suzuki, Y. Yasui, and T. Kasumi. 2005. Bio-functional components in the processed peregrinated brown rice by a twinscrew extruder. Journal of Food Comp. Ana. 18(4):303-316.

Omar JS, Yamashita R. 1987. Rice Drying, Husking and Milling- Part II Husking, Agricultural Mechanization in Asia, Africa and Latin America. 18: 43-46. 
Payman MH, Bagheri I, Alizadeh MR, Roohi R. 2006. Effective parameters of broken rice during paddy hulling using rubber roll huller. Journal of Biological Sciences. 7: 45-71.

Razavi, S.M.S. and R. Farahmandfar, 2008. Effect of hulling and milling on the physical properties of rice grains. Int Agrophysics, 22: 353359.

Shitanda D, Nishiyama Y, Koide S, 2001. Performance analysis of an impeller husker considering the physical and mechanical properties of paddy rice. J Agric Eng Res 79: 195-203.

Soliman, N. S., 1987. Hulling characteristics of two types of rubber roll paddy husker. Misr, J. Ag. Eng., 4 (1), 3-12.

Williams, J. F., J. F. Thomson, and R. G. Mutters, 2002. Rice milling quality. University of California Rice Research Quietly. Vol. 1 California.

Zhout, Z., and M. A. Mazad, 2002. Improving the rice post-harvest technology in Bangladesh. Agric. Mech. Asia, Africa and Latin America. 2002: 7: 37-43.

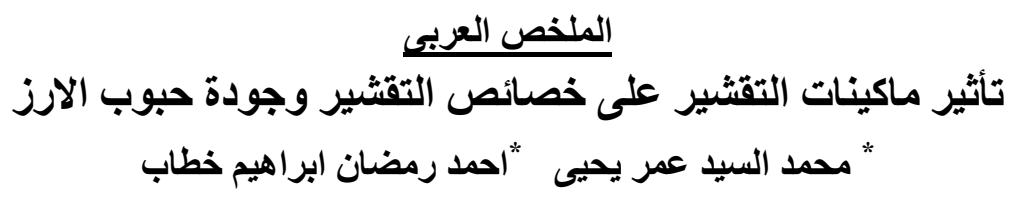

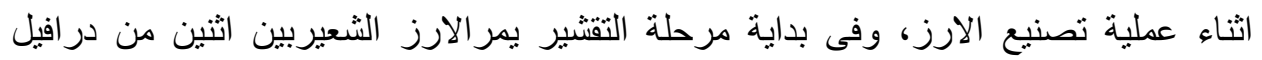

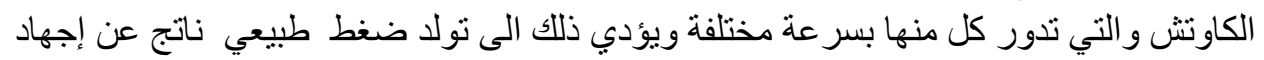

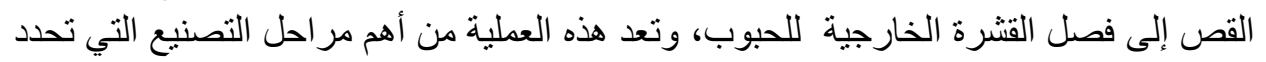

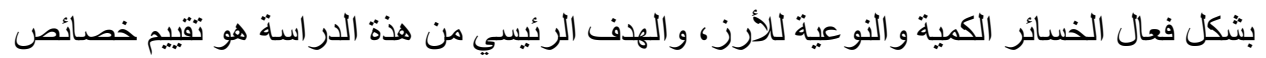

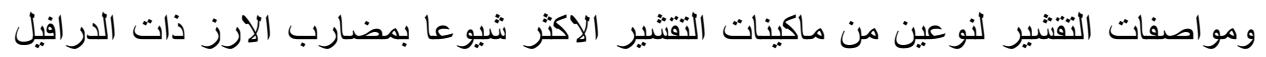

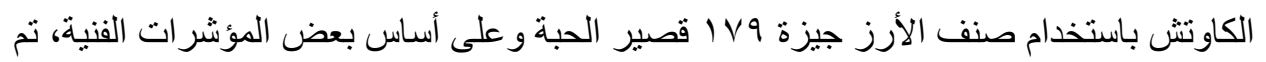

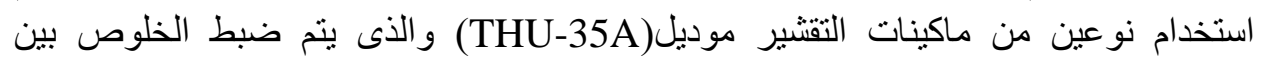

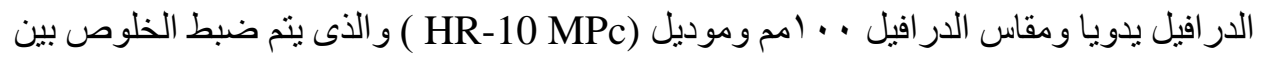

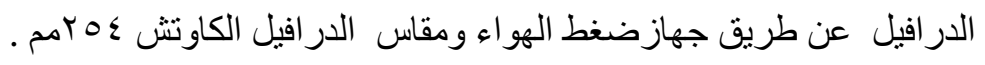

\footnotetext{
*باحث بمركز تدريب تكنولوجيا الأرز بالأسكندرية ـ معهد بحوث المحاصيل الحقلية - مركز
}

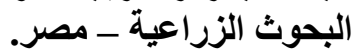




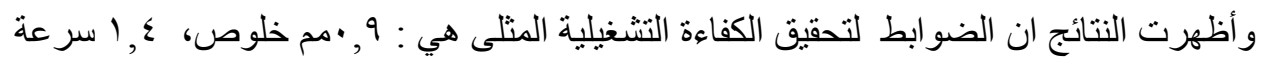
نسبية وذلك لماكينة التقشير موديل (THU-35A)، أما بالنسبة لماكينة التقثير موديل (

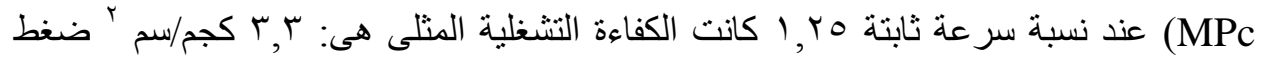
هو اء، ، 9 كجم/دقيقة معدل تغذية، ولوصف تأثثر كفاءة تقنير الأرز، تم استخدام النسبة المئوية للحبوب المكسورة واستهلاك الطاقة لآلات القتر كدالة لمعدل تغذية الأرز، ونسبة السرعة النسبية بين الدر افيل، تم استخدام برنامج رياضى على اساس الارتداد الخطى لوصف كفاءة التقتيرو العو امل الأخرى المرتبطة بعملية التقنير. 